\title{
Rationally Designed Probe for Reversible Sensing of Zinc and Application in Cells
}

\author{
Sabrina Heng, ${ }^{*}{ }^{\dagger} \odot$ Philipp Reineck, ${ }^{\perp}{ }^{\perp}$ Achini K. Vidanapathirana, ${ }^{\ddagger}$ Benjamin J. Pullen, ${ }^{\ddagger}$
} Daniel W. Drumm, ${ }^{\perp}$ Lesley J. Ritter ${ }^{\S}$ Nisha Schwarz, ${ }^{\ddagger}$ Claudine S. Bonder,, Peter J. Psaltis, ${ }^{\ddagger}$ Jeremy G. Thompson, ${ }^{\S}$ Brant C. Gibson, ${ }^{\perp \odot}$ Stephen J. Nicholls, ${ }^{\dagger}$ and Andrew D. Abell ${ }^{\dagger} \odot$

${ }^{\dagger}$ ARC Center of Excellence for Nanoscale BioPhotonics (CNBP), Institute for Photonics and Advanced Sensing (IPAS), Department of Chemistry, ${ }^{\ddagger}$ CNBP, Heart Health Theme, South Australian Health and Medical Research Institute and Adelaide Medicine School, ${ }^{\S}$ CNBP, IPAS, The Robinson Research Institute, School of Medicine, and "Centre for Cancer Biology, University of South Australia and SA Pathology \& Adelaide Medical School, The University of Adelaide, Adelaide, South Australia 5000, Australia

${ }^{\perp}$ CNBP, School of Science, RMIT University, Melbourne, Victoria 3001, Australia

\section{Supporting Information}

ABSTRACT: Biologically compatible fluorescent ion sensors, particularly those that are reversible, represent a key tool for answering a range of fundamental biological questions. We report a rationally designed probe with a $6^{\prime}$-fluoro spiropyran scaffold (5) for the reversible sensing of zinc $\left(\mathrm{Zn}^{2+}\right)$ in cells. The $6^{\prime}$-fluoro substituent overcomes several limitations normally associated with spiropyran-based sensors to provide an improved signal-tobackground ratio and faster photoswitching times in aqueous solution. In vitro studies were performed with 5 and the $6^{\prime}$-nitro analogues (6) in HEK 293 and endothelial cells. The new spiropyran (5) can detect exogenous $\mathrm{Zn}^{2+}$ inside both cell types and without affecting the proliferation of endothelial cells. Studies were also performed on dying HEK 293 cells, with results demonstrating the ability of the key compound to detect endogenous $\mathrm{Zn}^{2+}$ efflux from cells undergoing apoptosis. Biocompatibility and photoswitching of $\mathbf{5}$ were demonstrated within endothelial cells but not with $\mathbf{6}$, suggesting the future applicability of sensor $\mathbf{5}$ to study intracellular $\mathrm{Zn}^{2+}$ efflux in these systems.

\section{INTRODUCTION}

Fluorescent chemosensors capable of detecting, quantifying, and imaging specific molecules or ions are essential tools in cell biology and medical diagnostic imaging. ${ }^{1,2}$ An important advance in this area would come with the development of reversible sensors that allow continuous or repeated measurement within a biological sample. ${ }^{3}$ In this case, the sensor remains in a nonfluorescent state ("Off") in-between measurements and switches to a highly fluorescent state ("On") under an external stimulus, only when a measurement is required. The Off-On transition is controlled by a selected external stimulus (e.g., light). Such sensors allow multiple measurements to be conducted on a single sample without the need to change the sensor. This has clear advantages in biological applications where sample volume and availability are often limited. ${ }^{4}$

Spiropyrans are among the most extensively studied photoswitchable fluorophores used in such sensors. A spiropyran can be reversibly switched from a low-fluorescent spiro form (SP) to the highly fluorescent ring-opened merocyanine form (MC) on irradiation with UV light or on binding to a suitable analyte, for example, see Scheme $1 .^{5-9}$ This occurs with a high switching reliability and low fatigue to

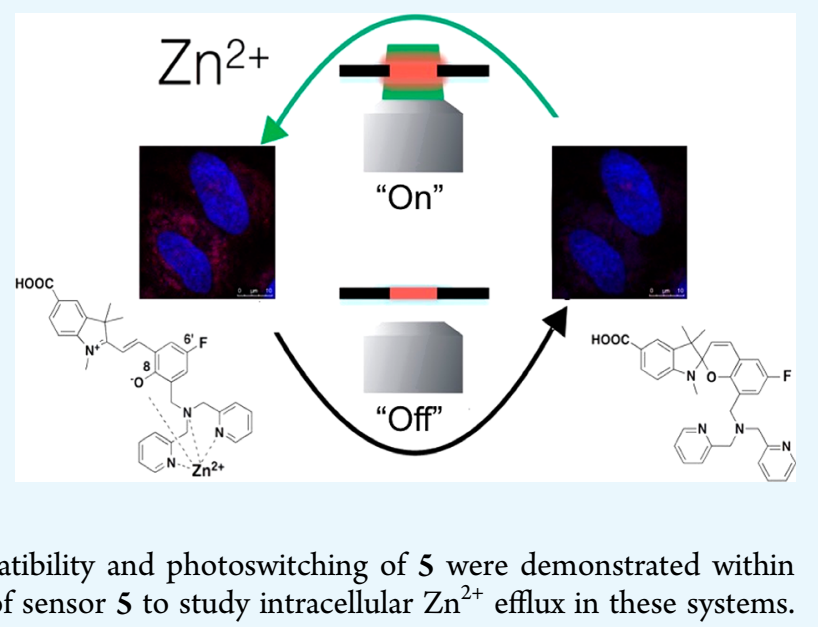

maximize the number of switching cycles between the two isomers. These structures have found wide use as a basis of reversible sensors for the detection of metal ions, ${ }^{10}$ amino acids, $^{11}$ and other species such as cyanide ion ${ }^{12}$ when appropriately functionalized to allow analyte binding to the MC isomer, for example, see $\mathrm{MC}-\mathrm{Zn}^{2+}$ in Scheme 1 .

The most common spiropyran scaffold used in these applications contains a $6^{\prime}$-nitro group on the chromene moiety (see Scheme 1, 6). ${ }^{13}$ This choice has a traditional basis, with these structures being readily prepared from nitro-substituted $o$ hydroxy aromatic aldehydes but also because the electron withdrawing $\mathrm{NO}_{2}$ substituent imparts high quantum yields for fluorescence-based sensing. Despite widespread use, these structures are somewhat problematic in biological systems because the photochromic characteristics of $6^{\prime}$-nitro-substituted spiropyrans are highly susceptible to the solvent environment. ${ }^{14}$ In general, the ring-closed spiro (SP) isomer is favored in nonpolar solvents, whereas the merocyanine isomer (MC) is

Received: July 4, 2017

Accepted: September 8, 2017

Published: September 27, 2017 
Scheme 1. Synthesis of Sensor 5 (i) Paraformaldehyde, $\mathrm{HBr}, 70{ }^{\circ} \mathrm{C}, 18 \mathrm{~h}, 72 \%$; (ii) Bis(2-pyridylmethyl)amine, $\mathrm{Et}_{3} \mathrm{~N}$, tetrahydrofuran (THF), Reflux, 18 h, 60-70\%; (iii) 4, Piperidine, EtOH, Reflux, 18 h, 20\% ${ }^{a}$

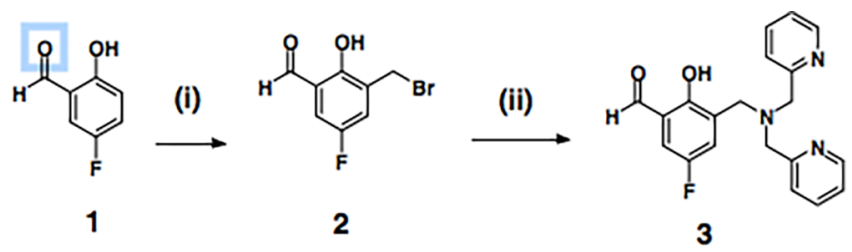

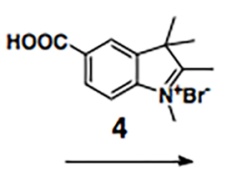

(iii)

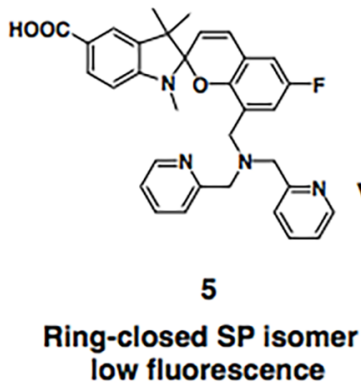

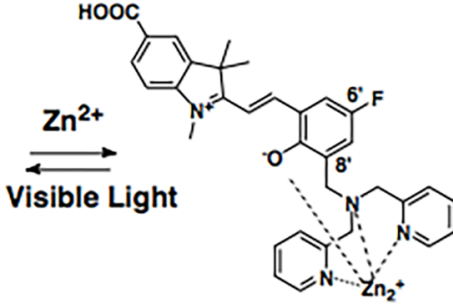

Ring-opened MC- $\mathrm{Zn}^{2+}$ isomer highly fluorescent

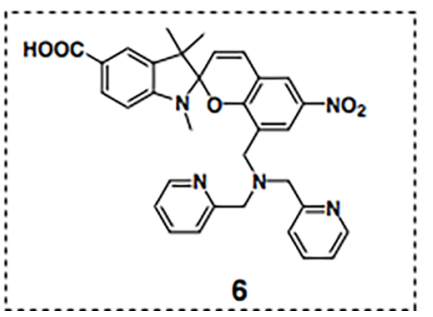

${ }^{a}$ Also shown are the isomeric structures of spiropyran in the absence and presence of $\mathrm{Zn}^{2+}$ and white light. Final structures of spiropyran (SP) and merocyanine isomers (MC) for sensor 5 are depicted, where the dashed lines depict bindings of $\mathrm{Zn}^{2+}$ to the $\mathrm{MC}$ ligand. The spiropyran- $\mathrm{Zn}{ }^{2+}$ sensing mechanism depicted here was reported by Rivera-Fuentes et al. on a similar analogue using density functional theory calculations. ${ }^{8}$ Also depicted is the $6^{\prime}-\mathrm{NO}_{2}$ analogue $(6$, boxed).

favored in polar solvents. ${ }^{15,16}$ The latter effect results in a high background fluorescence and poor signal-to-background ratio even in the absence of substrates, thus limiting sensitivity in sensor-based applications. The introduction of an electrondonating group (EDG), such as $t$-butyl ${ }^{17}$ or methyl, ${ }^{18}$ renders the photochromic properties of spiropyran less susceptible to these solvent effects. ${ }^{19}$ However, such analogues lack solubility in water and display significantly lower quantum yields with the loss of switching efficiency. ${ }^{20,21}$ All of this highlights a need to develop new spiropyran analogues with improved spectroscopic properties in aqueous media to further expand the use of spiropyrans in biological and other sensing applications.

Here, we present a new and rationally designed 6 '-fluoro substituted spiropyran sensor (see $\mathbf{5}$ in Scheme 1) that overcomes many of the before-mentioned limitations. A moderately electron withdrawing fluorine was incorporated to suppress photoisomerization in polar solvents, as is associated with the strongly electron withdrawing $\mathrm{NO}_{2}$ derivatives. This system was anticipated to retain relatively high fluorescence yields and aqueous solubility found in $\mathrm{NO}_{2}$-substituted derivatives but which is lost on incorporating an EDG group. $^{21} \mathrm{~A}$ bis(2-pyridylmethyl)amine substituent was incorporated into the spiropyran scaffold to promote binding of $\mathrm{Zn}^{2}$ to the ring-opened $\mathrm{MC}$ form, see Scheme 1. Sensor 5 contains an aryl carboxylate for increasing hydrophilicity as required for biological applications, while retaining cell permeability, as shown in previous studies. ${ }^{22} \mathrm{Zn}^{2+}$ was chosen for this study because of its essential role in a range of cellular processes, such as enzyme activity, structural integrity, and oocyte maturation and fertilization. ${ }^{23,24}$ Disruption of its homeostasis is also
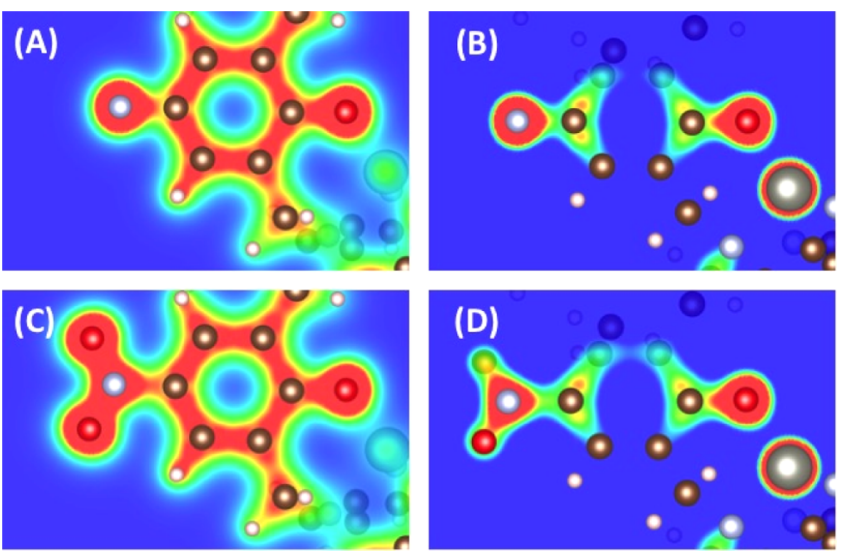

Figure 1. Images of electronic charge density of spiropyran 5 (A, B) and $6(C, D)$ in the presence of $\mathrm{Zn}^{2+}$ (gray). (A) and (C) show density in a best-fit plane to the functional group $\left(\mathrm{F}\right.$ and $\left.\mathrm{NO}_{2}\right)$, the benzopyran ring, and the $\mathrm{O}$ that bonds to the $\mathrm{Zn}^{2+}$. (B) and (D) show through the functional groups, the $\mathrm{O}$ and $\mathrm{Zn}^{2+}$, respectively. In addition, (A) and (C) show the electronic charge density around the benzopyran ring. The perspective is perpendicular to the plane shown in all cases. 


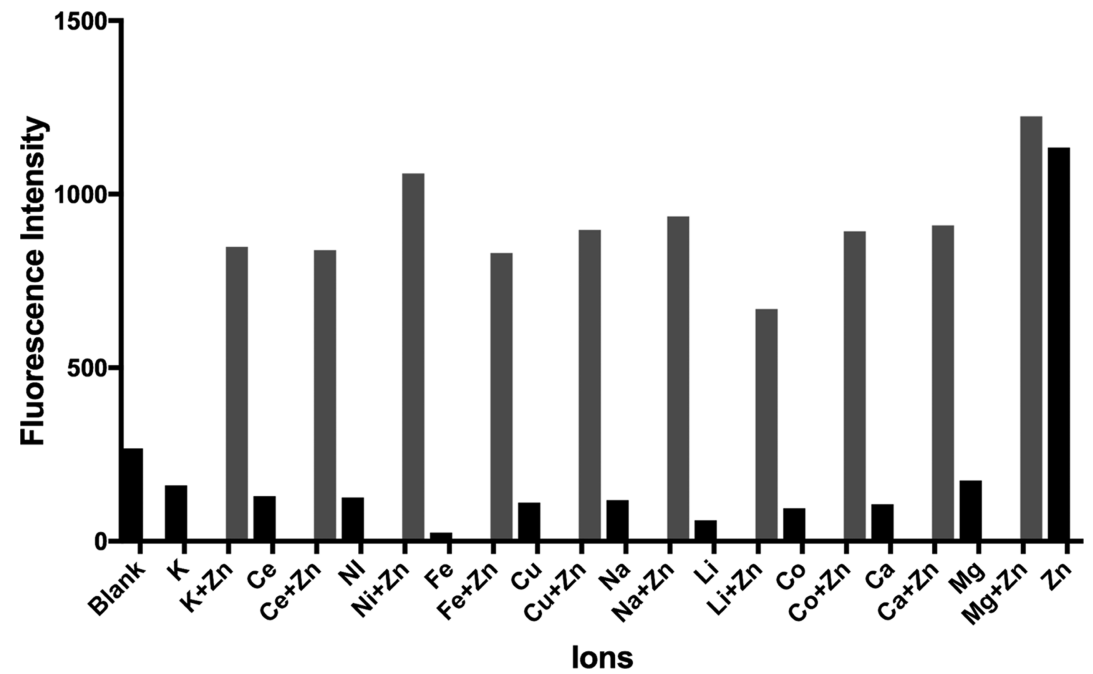

Figure 2. Selectivity of compound 5 (50 $\mu \mathrm{M}$ in water) against biologically relevant ions dissolved in $100 \mu \mathrm{M}$ of water. Metal ions were of the perchlorate or chloride form depending on availability. Black bars represent the fluorescence maximum $(\mathrm{Ex}=532 \mathrm{~nm}, \mathrm{Em}=670 \mathrm{~nm})$ obtained for sensor 5 incubated with a single metal ion. Gray bars represent the fluorescence maximum $(\mathrm{Ex}=532 \mathrm{~nm}$, Em $=670 \mathrm{~nm})$ obtained for sensor 5 incubated with 1:1 mixture of $\mathrm{Zn}^{2+}$ and a second ion. Experiments were carried out using 96-well plates. Data was processed using GraphPad Prism 7.

associated with numerous disease states such as cancer and Alzheimer's disease, ${ }^{25-27}$ and sensors for detecting $\mathrm{Zn}^{2+}$ in biology constitute the largest class of fluorescent indicators for transition metals. ${ }^{1,28-31}$

Despite $\mathrm{Zn}^{2+}$ being one of the most widely studied essential ions, its precise role in many biological processes is not well understood. For example, the relative harmful and protective effects of intracellular $\mathrm{Zn}^{2+}$ during endothelial cell function and apoptosis remain to be defined. ${ }^{32-34} \mathrm{Zn}^{2+}$ deficiency disrupts
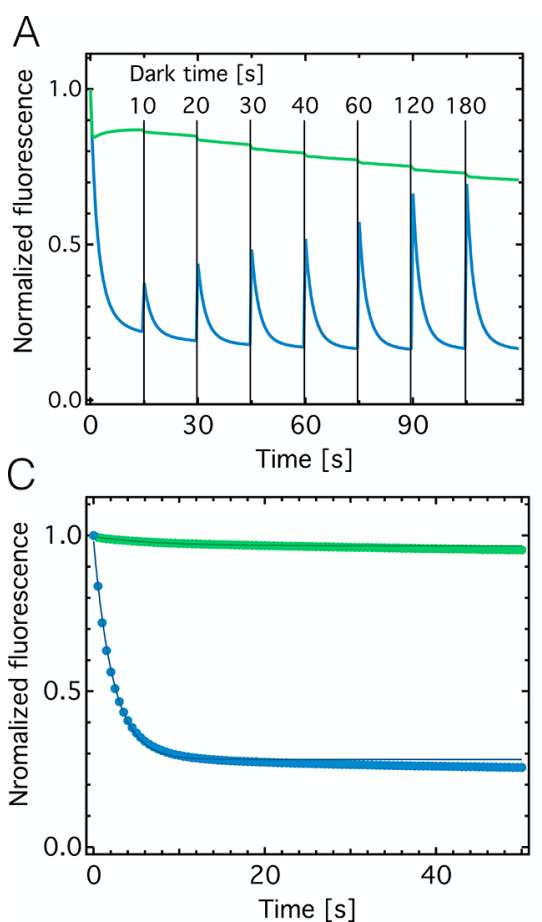

endothelial cell barrier function by various inflammatory, oxidative, and apoptotic agents in vitro, $33,35,36$ whereas physiological amounts of $\mathrm{Zn}^{2+}$ attenuate the endothelial dysfunction produced by the inflammatory cytokine, tumor necrosis factor $\alpha(\mathrm{TNF} \alpha) \cdot{ }^{37} \mathrm{~A}$ specific sensor for $\mathrm{Zn}^{2+}$ that can be turned on and off on demand would provide an opportunity to monitor changes in ion fluctuations and advance our knowledge of $\mathrm{Zn}^{2+}$ flux in various acute and chronic vascular
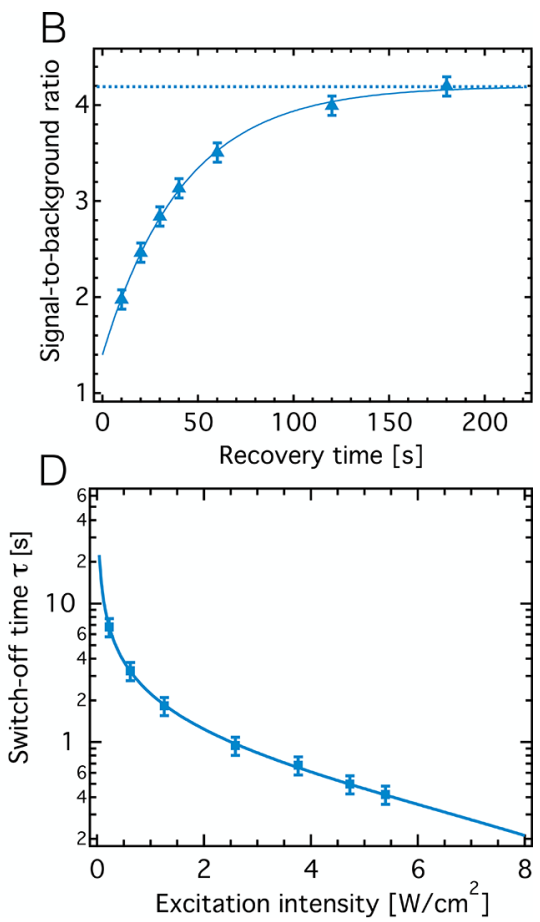

Figure 3. (A) Normalized fluorescence intensity as a function of time for Off/On cycles, with a fixed illumination time of $15 \mathrm{~s}$ and successively increasing time without any light exposure (recovery time), as indicated at the top of the graph. (B) The signal-to-background ratio as a function of the recovery time determined from (A). For increasing recovery times, compound $\mathbf{5}$ asymptotically approaches its maximum SBR 4.4 (dashed lines). The recovery dynamics are well described by a single exponential fit (solid lines), yielding recovery time constants $\tau_{\text {On }}$ of $42.1 \mathrm{~s}$ for 5 (C) Switch-off 

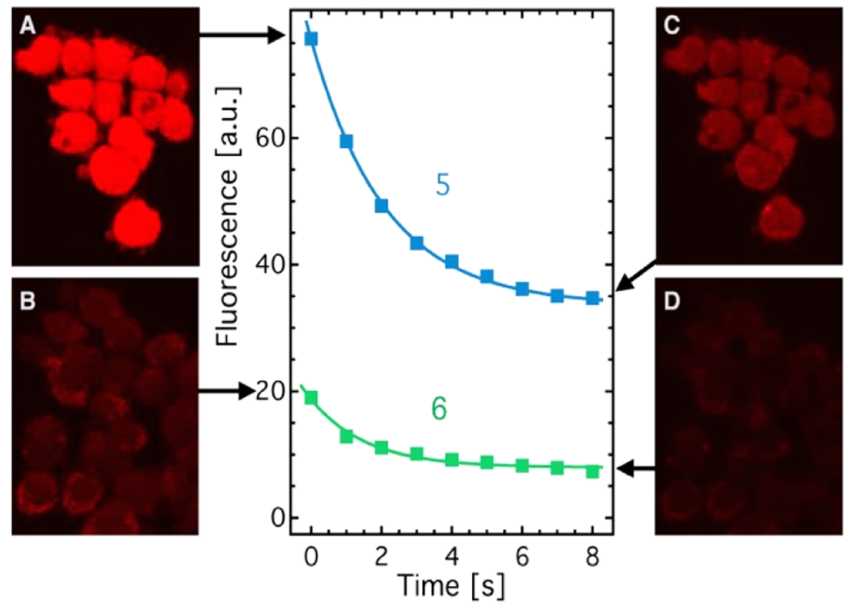

Figure 4. Comparison of fluorescence intensities of 5 (A, C) and 6 (B, D) in HEK 293 cells. The cells were irradiated $(559 \mathrm{~nm})$ and imaged for $8 \mathrm{~s}$, controlled by visible light from the confocal microscope. Fluorescence microscopy images of the cells at illumination time $t=0$ $(\mathrm{A}, \mathrm{B})$ and $t=8 \mathrm{~s}(\mathrm{C}, \mathrm{D})$ are shown. The graph in the center shows a typical fluorescence intensity evolution over time in arbitrary units (a.u.) obtained from fluorescence images of a selected group of cells. Photoswitching for sensor $\mathbf{5}$ was not observed after the first On/Off cycle.

disease processes, such as myocardial or cerebral infarction, atherosclerosis, and cancer related angiogenesis.

\section{RESULTS AND DISCUSSION}

Computational Analysis and Synthesis of Sensor 5. The ability of the $\mathrm{MC}$ isomer of 6-fluoro 5 to bind $\mathrm{Zn}^{2+}$, relative to previously reported 6-nitro $\mathbf{6}^{4,10}$ was first studied computationally (Vienna ab initio simulation package). ${ }^{38} \mathrm{MC} 6$ is known to show high selectivity for $\mathrm{Zn}^{2+}$ over other metal ions. The $\mathrm{Zn}^{2+}-9^{\prime}$-phenolic oxygen and $\mathrm{Zn}^{2+}-$ pyridine-nitrogen distances for sensor $\mathbf{5}$ and $\mathbf{6}$ were determined to be between 1.90 and $2.01 \AA$, with no significant difference between the two analogues (see Scheme 1 for substituent numbering scheme for the $\mathrm{MC}$ isomer). Interestingly, despite the substitution of $\mathrm{NO}_{2}$ for a less electron withdrawing $\mathrm{F}$ at the $6^{\prime}$ position on the chromene moiety, the electronic charge densities around the benzopyran ring for $\mathbf{5}$ and $\mathbf{6}$ are similar (Figure 1), with binding affinities calculated to the range 540$550 \mathrm{kcal} / \mathrm{mol}$. This suggests that both derivatives should display similar selectivity for $\mathrm{Zn}^{2+}$ (see Figure 1).

Sensor $\mathbf{5}$ was then synthesized as shown in Scheme 1. Benzylic bromide (2) was prepared by reaction of the $N$ substituted benzylaldehyde with paraformaldehyde in the presence of HBr. Reaction of these halides with bis(2pyridylmethyl) amine gave 3, respectively, which was reacted with $4,{ }^{39}$ with final purification by normal-phase chromatography, giving the desired sensor 5, as detailed in the Supporting Information section. ${ }^{1} \mathrm{H},{ }^{13} \mathrm{C}$ NMR spectra for sensor 5 can be found in the Supporting Information section.

Spectroscopic Analysis and Characterization of Sensor 5. The spectroscopic properties of sensor 5 and 6 were then compared to experimentally define the relative influence of the $6^{\prime}$-substituent to ion binding. The resulting absorbance spectra of sensors $\mathbf{5}$ and $\mathbf{6}$ are essentially identical, with a uniform 10-fold greater absorbance between 510 and $535 \mathrm{~nm}$ in the presence of $\mathrm{Zn}^{2+}$ compared to the spectra in the absence of the ion (see Figure S10 (Supporting Information)).
(A) $50 \mathrm{nM}$
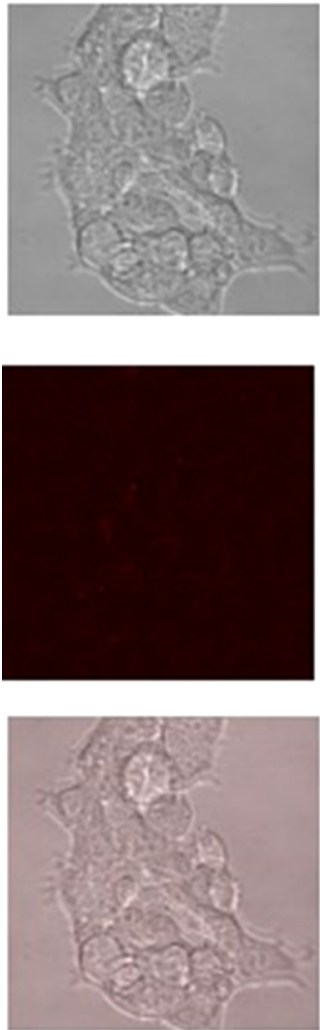

(B) $100 \mathrm{nM}$
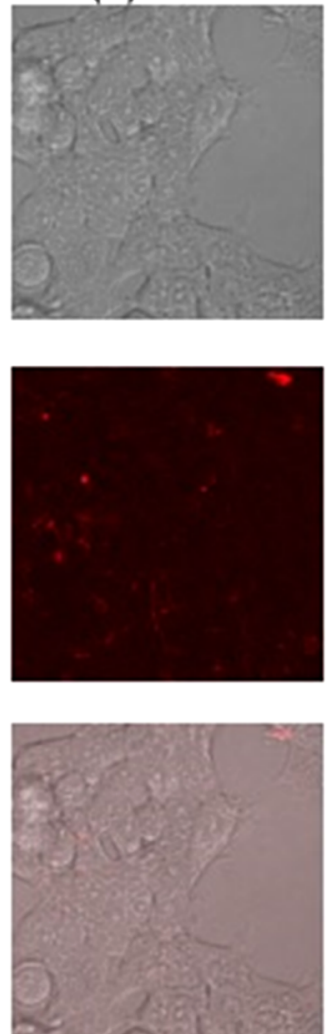

(C) $200 \mathrm{nM}$
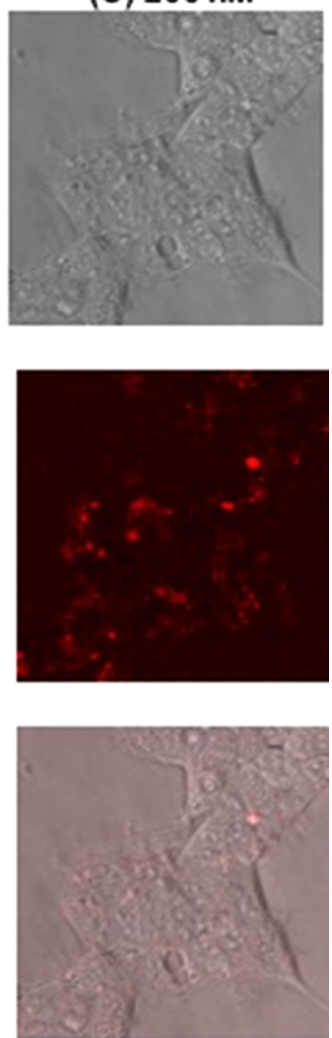

Figure 5. Confocal images of 5 incubated with HEK 293 cells treated with (A) $50 \mathrm{nM}$, (B) $100 \mathrm{nM}$, and (C) $200 \mathrm{nM}$ staurosporine; confocal images represented by (top row) phase contrast, (middle) red channel, and (bottom) merging. The addition of the cell-permeable chelator $N, N, N^{\prime}, N^{\prime}$ tetrakis(2-pyridylmethyl)ethylenediamine (TPEN) decreased the fluorescence, confirming that the fluorescence turn-on is induced by $\mathrm{Zn}^{2+}$. 
$\square 5$
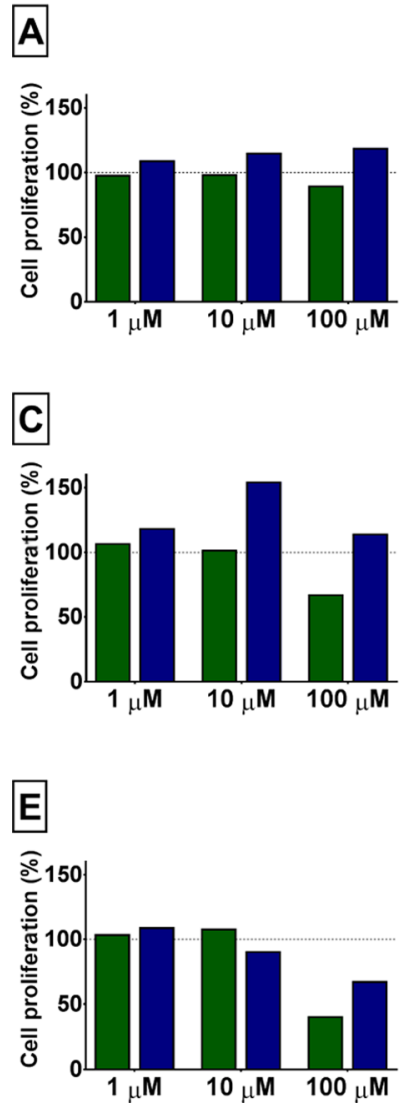

16

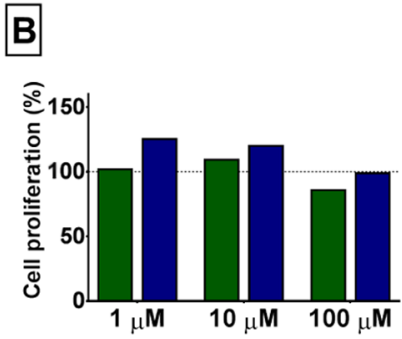

D

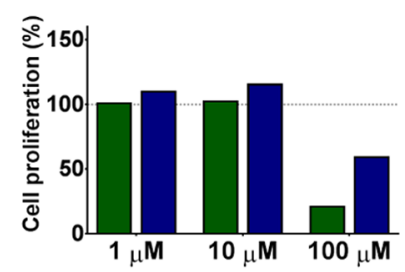

$\mathbf{F}$

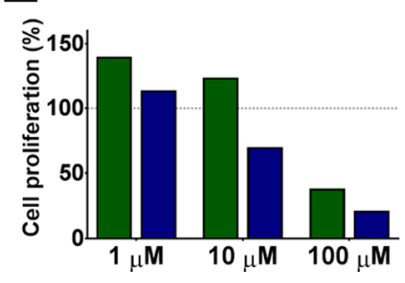

Figure 6. Absorbance at $450 \mathrm{~nm}$ in HUVECs with WST 1 reagent at six different time points of exposure to $0-100 \mu \mathrm{M}$ zinc sensor 5 or $\mathbf{6}$, to determine early and late effects of exposure to the sensor. Cell proliferation is expressed as a percentage, considering cell proliferation in the absence of sensor as $100 \%$ (dotted line). (A) Two hours with sensors, washed with culture media, and WST 1 assay after $24 \mathrm{~h}$. (B) Two hours with sensor, washed with culture media, and WST 1 assay after $72 \mathrm{~h}$. (C) Twelve hours with sensor and WST 1 assay at the end of exposure. (D) Twelve hours with sensor, washed with culture media, and WST 1 assay after $72 \mathrm{~h}$. (E) Twenty four hours with sensor and WST 1 assay at the end of exposure. (F) Seventy two hours with sensor and WST 1 assay at the end of exposure.

This increase in absorbance is the result of $\mathrm{Zn}^{2+}$-induced thermal switching to the more colored merocyanine state and indicates the formation of the $\mathrm{MC}-\mathrm{Zn}^{2+}$ complex in all cases (see Scheme 1). The formation of the $\mathrm{MC}-\mathrm{Zn}^{2+}$ complex was also verified by ${ }^{1} \mathrm{H}$ NMR and HRMS, as detailed in the Supporting Information section. Interestingly, the fluorescence emission maximum for $5(670 \mathrm{~nm})$ is significantly red shifted compared to 6 (615 nm, Figure S11 and Table S1 (Supporting Information)). The observed red shift for spiropyran $\mathbf{5}$ is advantageous for biological imaging because autofluorescence and scattering within tissues is minimal at these longer wavelengths. ${ }^{8}$ Next, the quantum yield of $\mathbf{5}$ in the presence of excess $\mathrm{Zn}^{2+}$ (i.e., $\mathrm{MC}(\mathbf{5}) / \mathrm{Zn}^{2+}$ complex) was determined to be 0.0028 using rhodamine $\mathrm{B}$ as the calibration standard, according to the method detailed in the Supporting Information section. The effect of the 6 -substituent is most pronounced here as quantum yield for $\mathrm{MC}(\mathbf{5}) / \mathrm{Zn}^{2+}$ is approximately 10 -fold less than that of $\mathrm{MC}(6) / \mathrm{Zn}^{2+}$. This is to be expected as the $6^{\prime}$-nitro is known to impart higher quantum yields for spiropyran-based molecules. The low quantum yield is not expected to greatly affect the performance of the sensor due to the low background in the absence of $\mathrm{Zn}^{2+}$.

Sensor 5 was next assayed against other biologically relevant metal ions $\left(\mathrm{Ca}^{2+}, \mathrm{Mg}^{2+}, \mathrm{Cu}^{2+}, \mathrm{Cs}^{+}, \mathrm{Pb}^{2+}, \mathrm{Al}^{3+}, \mathrm{Fe}^{2+}, \mathrm{Na}^{+}, \mathrm{Co}^{2+}\right.$, $\mathrm{K}^{+}, \mathrm{Ba}^{2+}, \mathrm{Mn}^{2+}$, and $\left.\mathrm{Be}^{+}\right)$and the results compared to data for $6{ }^{10}$ to characterize ion selectivity profiles. Results in Figure 2 show that spiropyran $\mathbf{5}$ was determined to be highly selective for $\mathrm{Zn}$ in the presence of other biologically relevant ions. The stoichiometry of binding of $\mathbf{5}$ and $\mathrm{Zn}^{2+}$ was determined to be 1:1 ( $\left.\mathrm{MC}(\mathbf{5}) / \mathrm{Zn}^{2+}\right)$ using Job's method of continuous variations, see Figure S12A (Supporting Information). Concentration-dependent curves show that the fluorescence of the new spiropyran $\mathbf{5}$ increased proportionally with increasing $\mathrm{Zn}^{2+}$ concentrations, where the limit of detection under these experimental conditions (with 5 at $50 \mu \mathrm{M}$ in water) was determined to be approximately $1 \mu \mathrm{M}$ (Figure $\mathrm{S} 12 \mathrm{~B}$ (Supporting Information)). This detection limit is well below that required for biological applications for diseased cells, where zinc concentrations are expected to increase on the order of micromolar. $^{30,40}$

Photoswitching between the fluorescent $\mathrm{MC}-\mathrm{Zn}^{2+}$ complexes and the nonfluorescent SP isomers of sensors 5 and 6 was next studied in detail. Aqueous solutions of compounds 5 and $6\left(0.8 \mathrm{mM}\right.$ in water) were premixed with $\mathrm{Zn}^{2+}$ ions $(2 \mathrm{mM}$ in water) in $20 \mu \mathrm{m}$ deep wells on a microscope slide and the fluorescence measured using modified glass slides and an automated commercial fluorescence microscope, as illustrated in Figure S13A,B (Supporting Information). Binding to $\mathrm{Zn}^{2+}$ ions caused an increase in the fluorescence for both spiropyrans, producing emission maxima between 615 and $680 \mathrm{~nm}$. Irradiation with white light, for photoswitching back to the SP isomer, resulted in a decreased fluorescence that is consistent with the nonphotoswitched intensity, demonstrating photoreversibility. Incubation of $\mathbf{5}$ with $\mathrm{Zn}^{2+}$ in the dark results in rebinding of $\mathrm{Zn}^{2+}$ and the formation of the fluorescent $\mathrm{Zn}^{2+}-\mathrm{MC}$ complexes. This was repeated over multiple cycles, with the results shown in Figure 3A. Sensor 5 showed clear photoswitching over the time course of the experiment without any apparent photobleaching (see blue traces in Figure 3A). Furthermore, switching dynamics for sensor $\mathbf{5}$ is well approximated by single exponential increase (On) and decay (Off), to give switch-on and off time constants of $\tau_{\mathrm{On}}=42 \mathrm{~s}$, $\tau_{\text {Off }}=2.2 \mathrm{~s}$ respectively (Figure $3 \mathrm{~B}, \mathrm{C}$ ). In comparison, multiple cycles of alternate irradiation with visible light and incubation in the dark did not give rise to photoswitching for 6 , with a decrease in fluorescence apparent over time, presumably due to photobleaching (Figure 3A, green). The steady state in fluorescence intensities of the On and Off state obtained is promising and future work will be focused on expanding the application of sensor $\mathbf{5}$ for repeated measurements in detecting $\mathrm{Zn}^{2+}$ in cells.

Cellular Studies 1: Sensing of $\mathrm{Zn}^{2+}$ in HEK 293 Cells. The relative abilities of $\mathbf{5}$ and $\mathbf{6}$ to reversibly sense $\mathrm{Zn}^{2+}$ in live cells was next examined. Separate solutions of spiropyrans $\mathbf{5}$ and $6(10 \mu \mathrm{M}$ in water) were incubated with HEK 293 cells pretreated with zinc perchlorate $(50 \mu \mathrm{M}$ in water) and zinc pyrithione $(20 \mu \mathrm{M}$ in water) for $30 \mathrm{~min}$ to facilitate the rapid accumulation of intracellular zinc. ${ }^{41}$ The thus formed MC$\mathrm{Zn}^{2+}$ complex was then irradiated with the $559 \mathrm{~nm}$ laser from the confocal microscope, which resulted in a red fluorescence within the cells characteristic with this complex (Figure 4A,C). Subsequent exposure of the cells to visible light for $8 \mathrm{~s}$ gave rise 

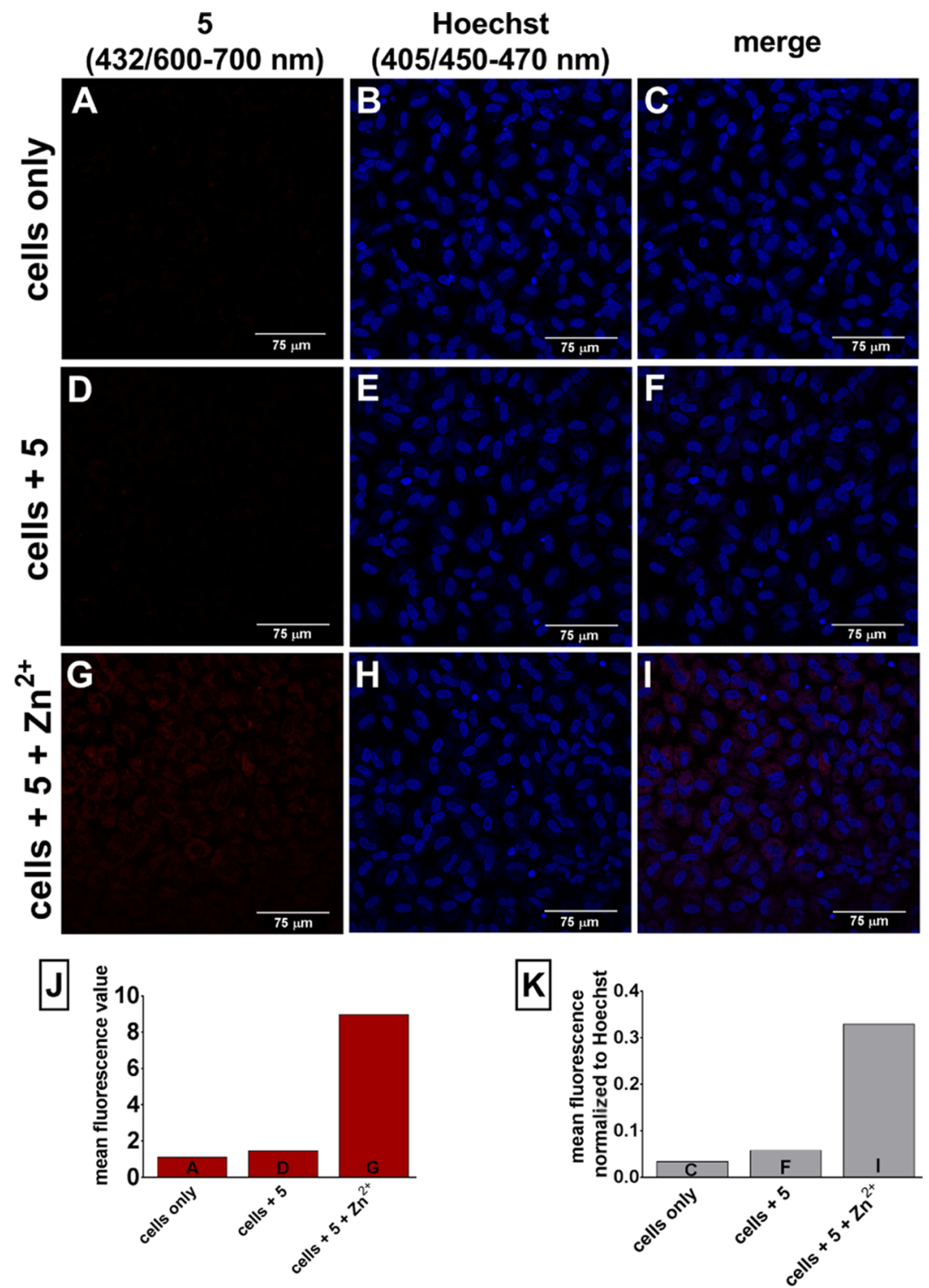

Figure 7. Confocal fluorescence images of 5 (10 $\mu \mathrm{M}$ in water) with HUVECs treated with exogenous $\mathrm{Zn}^{2+}$. (A), (D), and (G): HUVECs were excited by the $432 \mathrm{~nm}$ laser from the confocal microscope, and red emission was recorded (emission range $600-700 \mathrm{~nm}$ ) for $\mathrm{Zn}{ }^{2+}$ sensor 5. (B), (E), and $(\mathrm{H})$ : HUVECs were excited by the $405 \mathrm{~nm}$ laser from the confocal microscope, and blue emission was recorded (emission range $450-470 \mathrm{~nm}$ ) for Hoechst nuclear stain. (C), (F), and (I): the merged images from the two channels. (A)-(C) are from the cells with only negative control without the sensor. (D) $-(\mathrm{F})$ are after addition of the sensor $\mathbf{5}$ to get the baseline signal. (G) $-(\mathrm{I})$ are in the presence of exogenous $\mathrm{Zn}^{2+}$. The bar graphs at the bottom show the mean fluorescence value for sensor $\mathbf{5}$ of three images from each time point (J). These intensities were then normalized to the number of cells using Hoechst fluorescence $(\mathrm{K})$. Red = zinc sensor 5(432/600-700 nm), blue = Hoechst nuclear stain $(405 /$ $450-470 \mathrm{~nm})$.

to a decrease in fluorescence in both cases, consistent with the photoswitching from the fluorescent $\mathrm{MC}-\mathrm{Zn}^{2+}$ complex back to the nonfluorescent SP isomer, see Figure 3B,D. Repeated cycles of photoswitching gave reproducible changes in fluorescence, and as such both spiropyrans reversibly photoswitch in cells, see Figure 4. In contrast, photoswitching for $\mathbf{6}$ was not achieved after the first On/Off cycle and this observation is consistent with previous solution-based studies. Importantly, the red fluorescence was approximately $3 \times$ greater for 5 compared to that of $\mathbf{6}$ (Figure 4A,B). These results are consistent with the earlier solution-based observations, where the signal-to-background ratio for $\mathbf{5}$ is approximately three-fold better than the signal-to-background ratio for $\mathbf{6}$ (see Table S1 (Supporting Information)). This provides an important basis for probing changes in the intracellular $\mathrm{Zn}^{2+}$ level, where the high background fluorescence decreases the precision of fluorescence intensity measurements. ${ }^{42}$

Next, experiments were conducted to reveal the ability of the new and optimum sensor 5 to detect $\mathrm{Zn}^{2+}$ efflux from cells undergoing apoptosis. Dying cells are known to have increased levels of liable intracellular $\mathrm{Zn}^{2+}$ due to changes in the intracellular redox state liberating $\mathrm{Zn}^{2+}$ from protein thiolate bonds. ${ }^{43,44}$ Sensor 5 was incubated with (i) healthy cells (Figure S6 (Supporting Information)) and (ii) HEK 293 cells treated with 50-200 nM, staurosporine, a reagent known to induce apoptosis in cells. ${ }^{45}$ As before, changes in fluorescence and hence binding of $\mathbf{5}$ to intracellular $\mathrm{Zn}^{2+}$ were detected using confocal microscopy. Fluorescence was not observed in healthy cells (Figure S14 (Supporting Information)). In contrast, the results shown in Figure $5 \mathrm{~A}-\mathrm{C}$ clearly show red 

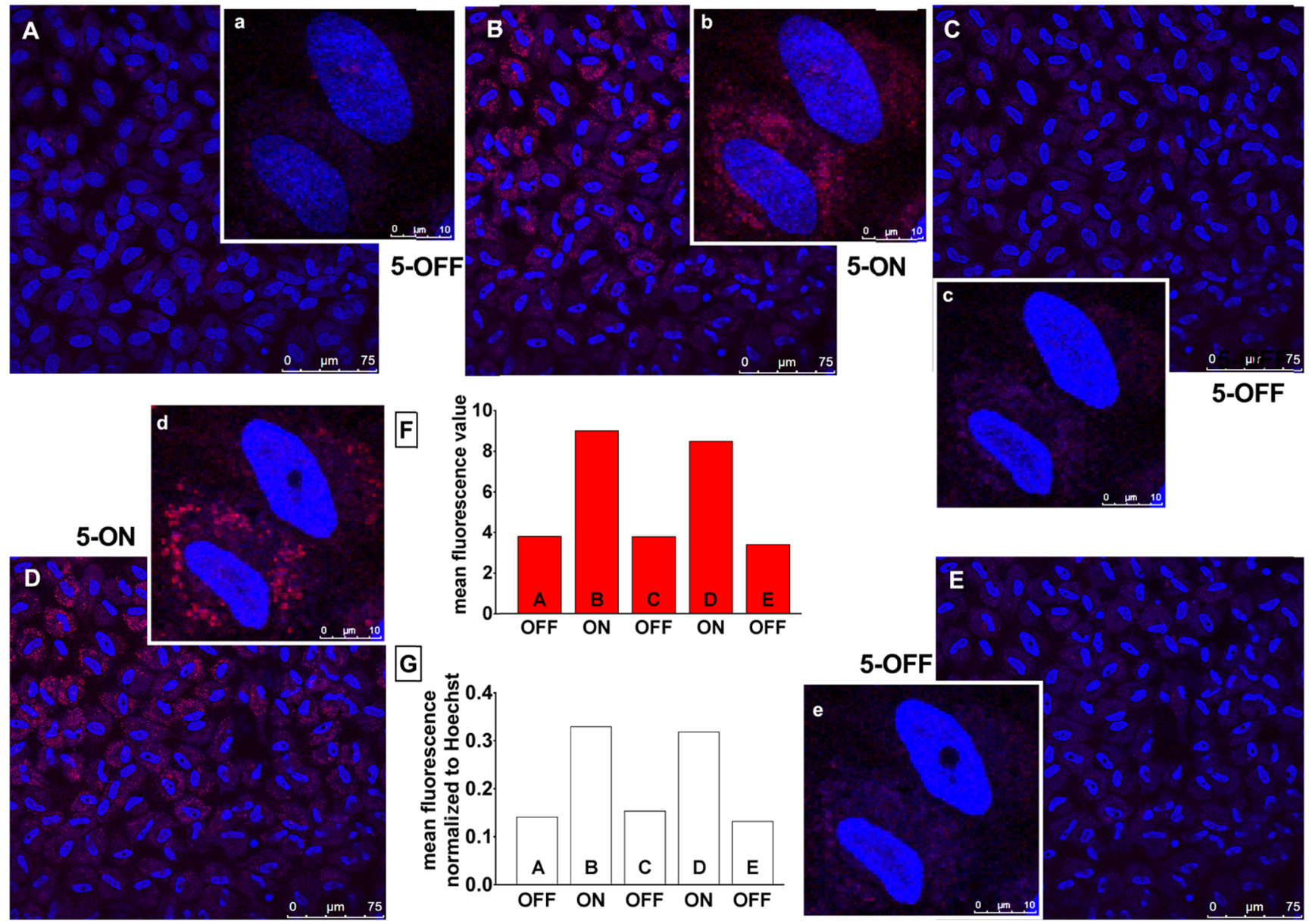

Figure 8. Comparison of fluorescence intensities of $\mathbf{5}$ in HUVEC and demonstration of the photoswitchable nature of the sensor. The cells were irradiated $(432 \mathrm{~nm})$ and imaged for $10 \mathrm{~s}$, controlled by visible light from the confocal microscope. Fluorescence microscopy images of the cells at irradiation time $t=0 \mathrm{~s}$ in (A), (C), and (E), Off, and $t=10 \mathrm{~s}(\mathrm{~B})$ and (D), On, are shown. The image panels (a) $-(\mathrm{e})$ are from two adjoining cells from panels $(\mathrm{A})-(\mathrm{E})$ and demonstrate how the intracellular signal changes with photoswitching. The bar graph at the bottom shows the mean fluorescence value of three images from each time point $(\mathrm{F})$. These intensities were then normalized to the number of cells using Hoechst fluorescence $(\mathrm{G})$. Red $=\mathrm{Zn}^{2+}$ sensor $5(432 / 600-700 \mathrm{~nm})$, blue $=$ Hoechst nuclear stain $(405 / 450-470 \mathrm{~nm})$.

fluorescence in dying cells as the concentration of staurosporine was increased, demonstrating the ability of $\mathbf{5}$ to detect endogenous $\mathrm{Zn}^{2+}$ efflux from cells undergoing apoptosis. This paves the way for use of $\mathbf{5}$ in cellular studies in particular, to understand the changes in intracellular zinc levels during apoptosis. $^{44}$

Cellular Studies 2: Sensing of Exogenous $\mathrm{Zn}^{2+}$ and Photoswitching Experiments in Endothelial Cells. The ability of $\mathbf{5}$ and $\mathbf{6}$ to detect $\mathrm{Zn}^{2+}$ was further assessed in human umbilical vein endothelial cells (HUVECs), a well-established model to study endothelial cell biology. First, HUVECs were separately incubated with $1 \mathrm{~nm}, 10 \mathrm{~nm}, 100 \mathrm{~nm}, 1 \mu \mathrm{M}, 10 \mu \mathrm{M}$, and $100 \mu \mathrm{M} 5$ or 6 for up to $72 \mathrm{~h}$ to examine and compare the effect of each sensor on cell proliferation, as determined by a colorimetric assay based on water soluble tetrazolium 1 (WST 1). The longer exposure times, particularly above $24 \mathrm{~h}$, are important for determining the toxicity of the sensors with prolonged incubation. The results in Figure 6 and in the corresponding Supporting Information section (Figures S15 and S16) show that concentrations up to $1 \mu \mathrm{M}$ of both sensors do not affect cell proliferation significantly. This is consistent with literature findings on general toxicity of spiropyrans. ${ }^{46}$ Significantly, endothelial cell growth was unaffected by incubation with sensor 5 at $10 \mu \mathrm{M}$ for up to $72 \mathrm{~h}$. In comparison, a marked decline in endothelial cell growth was observed with $>1 \mu \mathrm{M}$ sensor 6 (Figure 6).

Finally, the relative ability of 5 and 6 to reversibly sense $\mathrm{Zn}^{2+}$ in HUVECs was determined. Separate solutions of 5 and $\mathbf{6}(10$ $\mu \mathrm{M}$ in water) were incubated for $2 \mathrm{~h}$ with HUVECs pretreated with excess zinc perchlorate $(50 \mu \mathrm{M}$ in water) and zinc pyrithione $(20 \mu \mathrm{M}$ in water) for $30 \mathrm{~min}$ to facilitate rapid accumulation of intracellular $\mathrm{Zn}^{2+}$, as per previous experiments with HEK 293 cells. All HUVECs were counterstained with Hoechst 33342 to locate the nucleus. As before, the thus formed $\mathrm{MC}-\mathrm{Zn}^{2+}$ complexes 5 or $\mathbf{6}$ were irradiated with green laser from the confocal microscope, as detailed in the Supporting Information section. Results in Figures 7 and 8 show that sensor 5 shows an approximately 6-fold increase in red fluorescence within the cells' complex. Subsequent exposure of the cells to visible light for $10 \mathrm{~s}$ gave rise to a decrease in fluorescence, consistent with photoswitching from the fluorescent $\mathrm{MC}$ isomer back to the nonfluorescent $\mathrm{SP}$ isomer, see Figure 8. Photoswitching was not apparent for sensor 6 (10 $\mu \mathrm{M})$ under the same experimental conditions, with fluorescence intensities for 6 unexpectedly decreasing with the addition of $\mathrm{Zn}^{2+}$ (Figure 8). This is consistent with earlier solution-based experiments, where photoswitching for $\mathbf{6}$ was not observed (see Figure 3 ). These preliminary photoswitching 

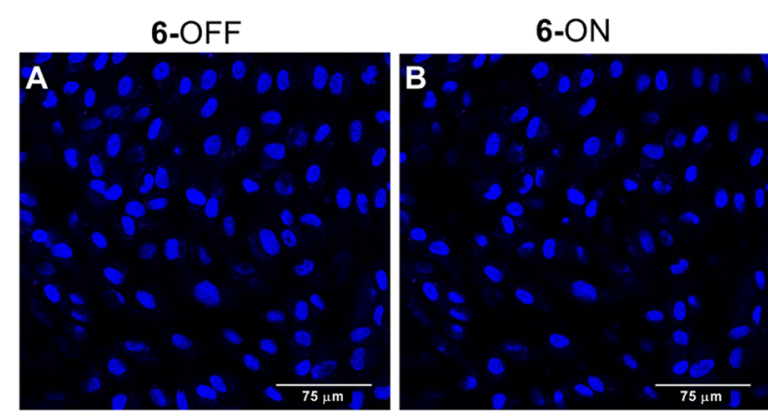

c
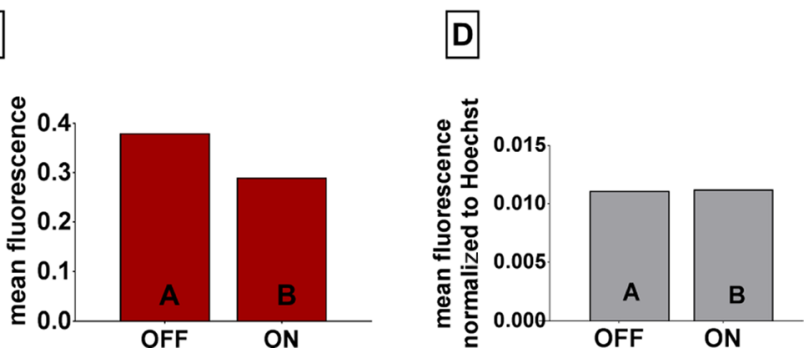

Figure 9. Comparison of fluorescence intensities of 6 in HUVECs to demonstrate the photoswitching characteristic of the sensor. The cells were irradiated $(532 \mathrm{~nm})$ and imaged for $10 \mathrm{~s}$, controlled by visible light from the confocal microscope. Fluorescence microscopy images of the cells at illumination time $t=0 \mathrm{~s}(\mathrm{~A})$ and $t=10 \mathrm{~s}(\mathrm{~B})$ are shown. The bar graph at the bottom shows the mean fluorescence value of three images from each time point (C). These intensities were then normalized to the number of cells using Hoechst fluorescence (D). Red $=$ zinc sensor 6 , blue $=$ Hoechst nuclear stain .

studies show that photoswitching clearly occurs with sensor 5 in HUVECs but not for 6 (Figure 9). In addition, cell detachment and reduced emission from Hoechst 33342 stain were also observed, possibly due to the interaction of 6 with the nuclear stain. These results are consistent with earlier cell proliferation studies discussed above and demonstrate that the $\mathrm{NO}_{2}$-substituted sensor (6) is not suitable for sensing applications in HUVECs. Ongoing work is focused on using $\mathbf{5}$ to study changes in intracellular $\mathrm{Zn}^{2+}$ levels in early to late passage endothelial cells (Figure 8).

\section{CONCLUSIONS}

$\mathrm{Zn}^{2+}$ is a ubiquitous cellular ion that plays a critical role in the modulation of fundamental cellular processes, and an ability to sense and determine fluctuations of its cellular concentration is central to many biological and medical applications. However, sensing $\mathrm{Zn}^{2+}$ is not straightforward as intracellular concentrations vary greatly during a typical cell cycle, with a variety of plasma membrane $\mathrm{Zn}^{2+}$ permeable channels and intracellular sources contributing to these fluctuations. Although several highly selective and sensitive fluorescent chemosensors for intracellular one-off sensing of $\mathrm{Zn}^{2+}$ are known, few can function reversibly and on demand. To meet this need, we have rationally designed and developed a new spiropyran-based sensor (5) with $\mathrm{F}$ at the $6^{\prime}$ position and a bis(2-pyridylmethyl)amine group as the ionophore to facilitate the binding of $\mathrm{Zn}^{2+}$. This single $F$ substitution gives rise to a significantly improved $\mathrm{Zn}^{2+}$ sensing and signal-to-background ratio, as well as faster photoswitching times in aqueous solution compared to existing spiropyran-based sensors. Importantly, cell toxicity was not observed for $\mathbf{5}$ within the concentrations used for sensing and an ability to reversibly sense $\mathrm{Zn}^{2+}$ in HEK 293 and endothelial cells is retained. We suggest this new spiropyran as the analytical tool of choice for a range of light-responsive zinc sensors and materials.

\section{EXPERIMENTAL SECTION}

Materials and Methods. Unless otherwise indicated, all starting materials, chemicals, and anhydrous solvents were purchased from Sigma-Aldrich (Australia) and were used without further purification. UNIBOND C-18 reverse-phase silica gel was purchased from Analtech Inc. Compound 4 (Scheme 1) was prepared as previously described. ${ }^{39}{ }^{1} \mathrm{H}$ and ${ }^{13} \mathrm{C}$ NMR spectra were recorded on a Varian $500 \mathrm{MHz}$ and Varian Inova $600 \mathrm{MHz}$ instruments in the indicated solvents. Chemical shifts are reported in $\mathrm{ppm}(\delta)$. Signals are reported as $\mathrm{s}$ (singlet), brs (broad singlet), d (doublet), dd (doublet of doublets), $\mathrm{t}$ (triplet), or $\mathrm{m}$ (multiplet). High-resolution mass spectra were collected using an LTQ Orbitrap XL ETD with flow injection, with a flow rate of $5 \mu \mathrm{L} \mathrm{min}{ }^{-1}$. Where indicated, compounds were analyzed and purified by reverse-phase HPLC, using an HP 1100 LC system equipped with a Phenomenex C-18 column $\left(250 \times 4.6 \mathrm{~mm}^{2}\right)$ for analytical traces and a Gilson GX-Prep HPLC system equipped with a Phenomenex C18 column $\left(250 \times 21.2 \mathrm{~mm}^{2}\right) \cdot \mathrm{H}_{2} \mathrm{O}$ and acetonitrile solutions were used as aqueous and organic buffers. All graphs were generated using GraphPad Prism 7 software and IgorPro 6. A mercury lamp (365 nm) and a halogen lamp $(>450 \mathrm{~nm})$ were used as the UV and visible light sources in photoswitching experiments.

3-(Bromomethyl)-5-fluoro-2-hydroxybenzaldehyde (2). A solution of 5-fluro-2-hydroxybenzaldehyde (5 g, $3.6 \mathrm{mmol})$ and paraformaldehyde (54 mmol, $1.6 \mathrm{~g}$ ) in $\mathrm{HBr}(20 \mathrm{~mL})$ was stirred at $70{ }^{\circ} \mathrm{C}$ for $20 \mathrm{~h}$. The reaction was quenched with water and extracted with dichloromethane $(20 \mathrm{~mL} \times 3)$. The organic layer was collected, dried with sodium sulfate, filtered, and excess solvent was removed under vacuo to yield the $\mathbf{2}$ as a yellow solid (6 g, 72\%). ${ }^{1} \mathrm{H} \mathrm{NMR}\left(500 \mathrm{MHz}, \mathrm{CDCl}_{3}\right) \delta 9.86(\mathrm{~s}$, $1 \mathrm{H}), 7.26$ (d, $J=2.50 \mathrm{~Hz}, 1 \mathrm{H}), 7.24(\mathrm{~d}, J=3.00 \mathrm{~Hz}, 1 \mathrm{H}), 4.54$ $(\mathrm{s}, 2 \mathrm{H}) .{ }^{13} \mathrm{C}$ NMR $\left(126 \mathrm{MHz}, \mathrm{DMSO}-d_{6}\right) \delta 195.3,128.3$, 125.4, 125.2, 120.3, 118.8, 118.6, 25.4.

3-((Bis(pyridin-2-ylmethyl)amino)methyl)-5-fluoro-2-hydroxybenzaldehyde (3). A solution of 2 (485 mg, $2.08 \mathrm{mmol})$, bis(2-pyridylmethyl)amine $(375 \mu \mathrm{L}, 2.08 \mathrm{mmol})$, and $\mathrm{Et}_{3} \mathrm{~N}$ $(580 \mu \mathrm{L}, 4.16 \mathrm{mmol})$ in anhydrous THF $(10 \mathrm{~mL})$ was set to reflux for $18 \mathrm{~h}$ and then concentrated in vacuo. The crude reaction mixture was purified using normal-phase silica gel (50-100\% ethyl acetate in hexane) to yield 3 as a yellow, viscous liquid (500 mg, 68\%). ${ }^{1} \mathrm{H}$ NMR $\left(500 \mathrm{MHz} \mathrm{CDCl}_{3}\right) \delta$ 10.49 (s, $1 \mathrm{H}), 8.59$ (d, $J=5.0 \mathrm{~Hz}, 2 \mathrm{H}), 7.66(\mathrm{td}, J=7.5,1.5 \mathrm{~Hz}$, $2 \mathrm{H}), 7.35-7.33(\mathrm{~m}, 3 \mathrm{H}), 7.21-7.19(\mathrm{~m}, 2 \mathrm{H}), 7.15$ (dd, $J=8.5$, $3.5 \mathrm{~Hz}, 1 \mathrm{H}), 3.92(\mathrm{~s}, 4 \mathrm{H}), 3.82(\mathrm{~s}, 2 \mathrm{H}) .{ }^{13} \mathrm{C} \mathrm{NMR}(126 \mathrm{MHz}$, DMSO- $\left.d_{6}\right) \delta 190.8,158.0(2 \mathrm{C}), 156.4,154.5,149.1$ (2C), 137.1 (2C), 127.5, 123.9, 123.2 (2C), 122.5 (2C), 113.0, 11.29, $59.2(2 \mathrm{C})$, 55.3. MS $(\mathrm{m} / z)$ for $-\mathrm{H}\left([\mathrm{M}-\mathrm{H}]^{-}\right)$calcd 350.1310; found 350.1305 .

8-((Bis(pyridin-2-ylmethyl)amino)methyl)-6-fluoro-1', 3', 3' trimethylspiro[chromene-2,2'-indoline]-5'-carboxylic Acid (5). A solution of $3(410 \mathrm{mg}, 1.17 \mathrm{mmol}), 4(254 \mathrm{mg}, 1.17$ $\mathrm{mmol})$, and piperidine $(116 \mu \mathrm{L}, 1.17 \mathrm{mmol})$ in anhydrous ethanol $(10 \mathrm{~mL})$ was set to reflux for $18 \mathrm{~h}$ and then concentrated under vacuo. The crude reaction mixture was purified using normal-phase silica $(5-10 \%$ methanol in dichloromethane) to yield 5 (295 $\mathrm{mg}, 46 \%)$ as a yellow solid. ${ }^{1} \mathrm{H}$ NMR (500 MHz, $\mathrm{CDCl}_{3}$ ) $\delta 8.56(\mathrm{~d}, J=4 \mathrm{~Hz}, 2 \mathrm{H}), 8.01$ 
(dd, $J=8.5,2.0 \mathrm{~Hz}, 1 \mathrm{H}), 7.80$ (apparent s, $1 \mathrm{H}), 7.65-7.63(\mathrm{~m}$, $3 \mathrm{H}), 7.53(\mathrm{~d}, J=8.0 \mathrm{~Hz}, 2 \mathrm{H}), 7.16-7.14(\mathrm{~m}, 3 \mathrm{H}), 6.81(\mathrm{~d}, J=$ $10.5 \mathrm{~Hz}, 1 \mathrm{H}), 6.69(\mathrm{dd}, J=8.0,3.0 \mathrm{~Hz}, 1 \mathrm{H}), 6.51(\mathrm{~d}, J=8.5$ $\mathrm{Hz}, 1 \mathrm{H}), 5.74(\mathrm{~d}, J=10.0 \mathrm{~Hz}, 1 \mathrm{H}), 3.76(\mathrm{~s}, 4 \mathrm{H}), 3.53-3.46(\mathrm{~m}$, $2 \mathrm{H}), 2.73(\mathrm{~s}, 3 \mathrm{H}), 1.32(\mathrm{~s}, 3 \mathrm{H}), 1.18(\mathrm{~s}, 3 \mathrm{H}) .{ }^{13} \mathrm{C}$ NMR (126 $\left.\mathrm{MHz}, \mathrm{DMSO}-d_{6}\right) \delta 169.74,159.31,157.88,157.68,155.79$, $151.73,148.88,148.65,147.65,136.90,136.35,131.74,129.09$, $127.06,123.58,123.11,122.56,122.42,122.13,119.96,116.20$ (2C), 111.58, 111.39, 105.85, 104.10, 59.61, 59.06, 51.21, 50.82, 28.68, $20.33(2 \mathrm{C})$. HRMS $(m / z)$ for $+\mathrm{H}\left([\mathrm{M}+\mathrm{H}]^{+}\right)$ calcd 551.2453; found 551.2460.

NMR spectrums $\left({ }^{1} \mathrm{H}\right.$ and $\left.{ }^{13} \mathrm{C}\right)$, HRMS, reverse-phase analytical HPLC traces of compound 5, additional experimental protocols and the associated graphs for (1) computational calculations, (2) spectroscopic analysis, and (3) cellular assays can be found in the Supporting Information section.

\section{ASSOCIATED CONTENT}

\section{S Supporting Information}

The Supporting Information is available free of charge on the ACS Publications website at DOI: 10.1021/acsomega.7b00923.

NMR spectrums $\left({ }^{1} \mathrm{H}\right.$ and $\left.{ }^{13} \mathrm{C}\right)$, HRMS, reverse-phase analytical HPLC traces of compound 5, additional experimental protocols, and the associated graphs for (1) computational calculations, (2) spectroscopic analysis, and (3) cellular assays (PDF)

\section{AUTHOR INFORMATION}

\section{Corresponding Author}

*E-mail: Sabrina.heng@adelaide.edu.au.

\section{ORCID}

Sabrina Heng: 0000-0002-2008-2790

Philipp Reineck: 0000-0003-1549-937X

Brant C. Gibson: 0000-0002-7109-2796

Andrew D. Abell: 0000-0002-0604-2629

\section{Author Contributions}

The manuscript was written through contributions of all authors.

\section{Notes}

The authors declare no competing financial interest.

\section{ACKNOWLEDGMENTS}

The authors acknowledge funding from the Centre for Nanoscale BioPhotonics through the Australian Research Council (ARC) CE140100 003 and National Health and Medical Research Council (NHMRC) of Australia, Principle Research Fellowship awarded to Prof. S.J. Nicholls (No. 1111630). This work was performed in part at the OptoFab node of the Australian National Fabrication Facility (ANFF) utilizing Commonwealth and South Australian State Government Funding. This work was supported by computational resources provided by the Australian Government through the National Computational Infrastructure under the National Computational Merit Allocation Scheme. The authors acknowledge Prof. Andrew Greentree (RMIT, Melbourne), Dr. Belinda Di Bartolo (SAHMRI), and Prof. Stephen J. Lippard and group (Massachusetts Institute of Technology) for helpful discussions.

\section{REFERENCES}

(1) Carter, K. P.; Young, A. M.; Palmer, A. E. Fluorescent sensors for measuring metal ions in living systems. Chem. Rev. 2014, 114, 45644601.

(2) Grimm, J. B.; English, B. P.; Chen, J.; Slaughter, J. P.; Zhang, Z.; Revyakin, A.; Patel, R.; Macklin, J. J.; Normanno, D.; Singer, R. H.; Lionnet, T.; Lavis, L. D. A general method to improve fluorophores for live-cell and single-molecule microscopy. Nat. Methods 2015, 12, 244250

(3) Natali, M.; Giordani, S. Molecular switches as photocontrollable "smart" receptors. Chem. Soc. Rev. 2012, 41, 4010-4029.

(4) Heng, S.; McDevitt, C. A.; Kostecki, R.; Morey, J. R.; Eijkelkamp, B. A.; Ebendorff-Heidepriem, H.; Monro, T. M.; Abell, A. D. Microstructured Optical Fiber-based Biosensors: Reversible and Nanoliter-Scale Measurement of Zinc Ions. ACS Appl. Mater. Interfaces 2016, 8, 12727-12732.

(5) Klajn, R. Spiropyran-based dynamic materials. Chem. Soc. Rev. 2014, 43, 148-184.

(6) Heng, S.; Nguyen, M. C.; Kostecki, R.; Monro, T. M.; Abell, A. D. Nanoliter-scale, regenerable ion sensor: sensing with a surface functionalized microstructured optical fibre. RSC Adv. 2013, 3, 83088317.

(7) Heng, S.; Mak, A. M.; Stubing, D. B.; Monro, T. M.; Abell, A. D. Dual sensor for $\mathrm{Cd}(\mathrm{II})$ and $\mathrm{Ca}(\mathrm{II})$ : selective nanoliter-scale sensing of metal ions. Anal. Chem. 2014, 86, 3268-3272.

(8) Rivera-Fuentes, P.; Lippard, S. J. SpiroZin1: a reversible and $\mathrm{pH}-$ Insensitive, reaction-based, red-fluorescent probe for imaging biological mobile zinc. ChemMedChem 2014, 9, 1238-1243.

(9) Natali, M.; Soldi, L.; Giordani, S. A photoswitchable Zn (II) selective spiropyran-based sensor. Tetrahedron 2010, 66, 7612-7617.

(10) Heng, S.; McDevitt, C. A.; Stubing, D. B.; Whittall, J. J.; Thompson, J. G.; Engler, T. K.; Abell, A. D.; Monro, T. M. Microstructured optical fibers and live cells: a water-soluble, photochromic zinc sensor. Biomacromolecules 2013, 14, 3376-3379.

(11) Shao, N.; Jin, J. Y.; Cheung, S. M.; Yang, R. H.; Chan, W. H.; Mo, T. A spiropyran-based ensemble for visual recognition and quantification of cysteine and homocysteine at physiological levels. Angew. Chem., Int. Ed. Engl. 2006, 45, 4944-4948.

(12) Shiraishi, Y.; Adachi, K.; Itoh, M.; Hirai, T. Spiropyran as a selective, sensitive, and reproducible cyanide anion receptor. Org. Lett. 2009, 11, 3482-3485.

(13) Lukyanov, B. S.; Lukyanova, M. B. Spiropyrans: Synthesis, Properties and Application. A Review. Chem. Heterocycl. Compd. 2005, 41, 281-311.

(14) Tian, W.; Tian, J. An insight into the solvent effect on photo-, solvato-chromism of spiropyran through the perspective of intermolecular interactions. Dyes Pigm. 2014, 105, 66-74.

(15) Swansburg, S.; Buncel, E.; Lemieux, R. P. Thermal racemization of substituted indolinobenzospiropyrans: Evidence of competing polar and nonpolar mechanisms. J. Am. Chem. Soc. 2000, 122, 6594-6600.

(16) Shiraishi, Y.; Inoue, T.; Sumiya, S.; Hirai, T. Entropy-Driven Thermal Isomerization of Spiropyran in Viscous Media. J. Phys. Chem. A 2011, 115, 9083-9090.

(17) Shao, N.; Wang, H.; Gao, X.; Yang, R.; Chan, W. Spiropyranbased fluorescent anion probe and its application for urinary pyrophosphate detection. Anal. Chem. 2010, 82, 4628-4636.

(18) Rivera-Fuentes, P.; Wrobel, A. T.; Zastrow, M. L.; Khan, M.; Georgiou, J.; Luyben, T. T.; Roder, J. C.; Okamoto, K.; Lippard, S. J. A Far-Red Emitting Probe for Unambiguous Detection of Mobile Zinc in Acidic Vesicles and Deep Tissue. Chem. Sci. 2015, 6, 1944-1948.

(19) Shao, N.; Jin, J.; Wang, H.; Zheng, J.; Yang, R.; Chan, W.; Abliz, Z. Design of bis-spiropyran ligands as dipolar molecule receptors and application to in vivo glutathione fluorescent probes. J. Am. Chem. Soc. 2010, 132, 725-736.

(20) Rivera-Fuentes, P.; Wrobel, A. T.; Zastrow, M. L.; Khan, M.; Georgiou, J.; Luyben, T. T.; Roder, J. C.; Okamoto, K.; Lippard, S. J. A Far-Red Emitting Probe for Unambiguous Detection of Mobile Zinc in Acidic Vesicles and Deep Tissue. Chem. Sci. 2015, 6, 1944-1948. 
(21) Kohl-Landgraf, J.; Braun, M.; Ozcoban, C.; Goncalves, D. P.; Heckel, A.; Wachtveitl, J. Ultrafast dynamics of a spiropyran in water. J. Am. Chem. Soc. 2012, 134, 14070-14077.

(22) Heng, S.; Mak, A. M.; Kostecki, R.; Zhang, X.; Pei, J.; Stubing, D. B.; Ebendorff-Heidepriem, H.; Abell, A. D. Photoswitchable calcium sensor: 'On'-'Off sensing in cells or with microstructured optical fibers. Sens. Actuators, B 2017, 252, 965-972.

(23) Formigari, A.; Gregianin, E.; Irato, P. The effect of zinc and the role of p53 in copper-induced cellular stress responses. J. Appl. Toxicol. 2013, 33, 527-536

(24) Kim, A. M.; Bernhardt, M. L.; Kong, B. Y.; Ahn, R. W.; Vogt, S.; Woodruff, T. K.; O'Halloran, T. V. Zinc sparks are triggered by fertilization and facilitate cell cycle resumption in mammalian eggs. ACS Chem. Biol. 2011, 6, 716-723.

(25) Wang, C. Y.; Wang, T.; Zheng, W.; Zhao, B. L.; Danscher, G.; Chen, Y. H.; Wang, Z. Y. Zinc overload enhances APP cleavage and Abeta deposition in the Alzheimer mouse brain. PLoS One 2010, 5, No. e15349.

(26) Maynard, C. J.; Bush, A. I.; Masters, C. L.; Cappai, R.; Li, Q. X. Metals and amyloid-beta in Alzheimer's disease. Int. J. Exp. Pathol. 2005, 86, 147-159.

(27) VanLandingham, J. W.; Fitch, C. A.; Levenson, C. W. Zinc inhibits the nuclear translocation of the tumor suppressor protein p53 and protects cultured human neurons from copper-induced neurotoxicity. NeuroMol. Med. 2002, 1, 171-182.

(28) Guo, Z.; Kim, G. H.; Yoon, J.; Shin, I. Synthesis of a highly $\mathrm{Zn}(2+)$-selective cyanine-based probe and its use for tracing endogenous zinc ions in cells and organisms. Nat. Protoc. 2014, 9, $1245-1254$

(29) Zastrow, M. L.; Radford, R. J.; Chyan, W.; Anderson, C. T.; Zhang, D. Y.; Loas, A.; Tzounopoulos, T.; Lippard, S. J. ReactionBased Probes for Imaging Mobile Zinc in Live Cells and Tissues. ACS Sens. 2016, 1, 32-39.

(30) Maret, W. Analyzing free zinc(II) ion concentrations in cell biology with fluorescent chelating molecules. Metallomics 2015, 7, 202-211.

(31) Zhang, D. Y.; Azrad, M.; Demark-Wahnefried, W.; Frederickson, C. J.; Lippard, S. J.; Radford, R. J. Peptide-based, two-fluorophore, ratiometric probe for quantifying mobile zinc in biological solutions. ACS Chem. Biol. 2015, 10, 385-389.

(32) Wiseman, D. A.; Wells, S. M.; Hubbard, M.; Welker, J. E.; Black, S. M. Alterations in zinc homeostasis underlie endothelial cell death induced by oxidative stress from acute exposure to hydrogen peroxide. Am. J. Physiol.: Lung Cell. Mol. Physiol. 2007, 292, L165-177.

(33) Juriol, L. V.; Gobetto, M. N.; Mendes Garrido Abregu, F.; Dasso, M. E.; Pineda, G.; Guttlein, L.; Carranza, A.; Podhajcer, O.; Toblli, J. E.; Elesgaray, R.; Arranz, C. T.; Tomat, A. L. Cardiac changes in apoptosis, inflammation, oxidative stress, and nitric oxide system induced by prenatal and postnatal zinc deficiency in male and female rats. Eur. J. Nutr. 2016, 1-15.

(34) Shearier, E. R.; Bowen, P. K.; He, W.; Drelich, A.; Drelich, J.; Goldman, J.; Zhao, F. In Vitro Cytotoxicity, Adhesion, and Proliferation of Human Vascular Cells Exposed to Zinc. ACS Biomater. Sci. Eng. 2016, 2, 634-642.

(35) Cortese-Krott, M. M.; Suschek, C. V.; Wetzel, W.; Kroncke, K. D.; Kolb-Bachofen, V. Nitric oxide-mediated protection of endothelial cells from hydrogen peroxide is mediated by intracellular zinc and glutathione. Am. J. Physiol.: Cell Physiol. 2009, 296, C811-820.

(36) Hennig, B.; Meerarani, P.; Ramadass, P.; Toborek, M.; Malecki, A.; Slim, R.; McClain, C. J. Zinc nutrition and apoptosis of vascular endothelial cells: implications in atherosclerosis. Nutrition 1999, 15, 744-748.

(37) Meerarani, P.; Ramadass, P.; Toborek, M.; Bauer, H. C.; Bauer, H.; Hennig, B. Zinc protects against apoptosis of endothelial cells induced by linoleic acid and tumor necrosis factor alpha. Am. J. Clin. Nutr. 2000, 71, 81-87.

(38) Kresse, G.; Furthmuller, J. Efficient iterative schemes for ab initio total-energy calculations using a plane-wave basis set. Phys. Rev. B: Condens. Matter Mater. Phys. 1996, 54, 11169-11186.
(39) Heng, S.; Nguyen, M.; Kostecki, R.; Monro, T. M.; Abell, A. D. Nanoliter-scale, regenerable ion sensor: sensing with a surface functionalized microstructured optical fiber. RSC $A d v$. 2013, 3, $8308-8317$.

(40) Truong-Tran, A. Q.; Ho, L. H.; Chai, F.; Zalewski, P. D. Cellular zinc fluxes and the regulation of apoptosis/gene-directed cell death. J. Nutr. 2000, 130, 1459s-1466s.

(41) Gee, K. R.; Zhou, Z. L.; Ton-That, D.; Sensi, S. L.; Weiss, J. H. Measuring zinc in living cells. A new generation of sensitive and selective fluorescent probes. Cell Calcium 2002, 31, 245-251.

(42) Waters, J. C. Accuracy and precision in quantitative fluorescence microscopy. J. Cell Biol. 2009, 185, 1135-1148.

(43) Truong-Tran, A. Q.; Ruffin, R. E.; Zalewski, P. D. Visualization of labile zinc and its role in apoptosis of primary airway epithelial cells and cell lines. Am. J. Physiol.: Lung Cell. Mol. Physiol. 2000, 279, L1172-1183.

(44) Chai, F.; Truong-Tran, A. Q.; Ho, L. H.; Zalewski, P. D. Regulation of caspase activation and apoptosis by cellular zinc fluxes and zinc deprivation: A review. Immunol. Cell Biol. 1999, 77, 272-278.

(45) Belmokhtar, C. A.; Hillion, J.; Segal-Bendirdjian, E. Staurosporine induces apoptosis through both caspase-dependent and caspase-independent mechanisms. Oncogene 2001, 20, 33543362.

(46) Movia, D.; Prina-Mello, A.; Volkov, Y.; Giordani, S. Determination of spiropyran cytotoxicity by high content screening and analysis for safe application in bionanosensing. Chem. Res. Toxicol. 2010, 23, 1459-1466. 